\title{
THE CONSTRUCTION LABOUR SHORTAGE IN JOHOR BAHRU, MALAYSIA
}

\author{
Abdul Rahim Abdul Hamid, Bachan Singh Besawa Jagar Singh ${ }^{2}$, Muhammad Shahrom Mazlan ${ }^{3}$ \\ ${ }^{1,2}$ Senior Lecturer, ${ }^{3}$ Project Engineer, Department of Structures and Materials, Faculty of Civil Engineering, Universiti \\ Teknologi Malaysia, 81310 UTM Johor Bahru, Johor Darul Ta'zim, Malaysia. \\ rahimfka@gmail.com, bachan19@yahoo.com,matshah_125@yahoo.com.my
}

\begin{abstract}
Construction industry is one of the sectors that require the Labor intensive to fulfill the work site. However, we always hear the problems related to the shortage of the construction workers. Therefore, the purpose of this study are to estimate the current shortage composition of construction labor, to evaluate the problem faced by contractor when hired labor, to examine contractor method of acquiring construction labor, and to investigate the strategies taken by contractor to overcome shortage of labor. The questionnaire will be distributed to the 35 of construction site which targeting project representative that involved with construction site in Johor Bahru district, Malaysia, in order to obtain their feedback related to this topic. The Johor Bahru district is located in the southern part of Johor in the Malay Peninsula, separated from Singapore by Straits of Johor. The district covers an area of 1,871 km and has a population of over 2 million. The data will be analyzed using SPSS 16 in order to obtain average index, frequencies and percentage calculation. The result obtained from analysis will be represent in data table, bar and pie chart. The result of this study indicates that the current shortage and demand of the current construction are about 12.14\% from the total labor workforce which is about 360 workers for 35 projects sites.
\end{abstract}

Keywords: Construction, Foreign Workers, Shortage, Strategies $* * *$

\section{INTRODUCTION}

The construction industry is among the most important industries in the country that closely related to other economic sectors. It is the capital goods industry to provide infrastructure for other industries operation. The construction industry also is a sector becomes the engine of economic growth and most resources are used for national development (Zakaria, M.Y, 2006)[1]. The construction project depends on project resources. Among the most important resources is the source of workers. Shortage of labor resources in Malaysia resulting, the country depends on the labor workforce from outside, especially from Indonesia [2, 3]. Scenarios for the recruitment of foreign workers in the construction sector in Malaysia not a new issue. Malaysia has started taking foreign workers since the reign of the British. Malaysia is the biggest net importer of labor in Asia with a migrant labor force of around 2 million (21 percent of 9.5 million of the total work force) as of 2010 (Migration News, 2011)[4]. Construction was among the sectors which came to rely heavily on foreign workers owing to a confluence of factors: Malaysian youth's aversion to low status work, an expanding manufacturing sector which was offering much better employment conditions, labor attrition, widening opportunities for tertiary education, a lower birth rate and the emigration of Malaysian workers to high-wage countries such as Japan and Singapore
(Abdul-Aziz, 1995)[5,6]. Datuk Ir. Hamzah Hasan, Chief Executive, CIDB revealed that there are about 300,000 legal foreign construction workers in addition to 391,006 local workforce (43\% of the total construction workers)( Malaysian Construction Summit 2008)[7].

From the statistic show that the foreign workers involved in construction sector is around 361,000 workers. From the study conducted by CIDB about the status construction workers and local which covered the skilled workers, semi skilled workers and unskilled workers at construction site, revealed that $52 \%$ (361,000 workers) are from foreigner workers contributing to total workforce construction industry, while $48 \%$ (333,000 workers) are local workers (CIDB \& CREAM, 2010)[8]. From the total foreign construction workers $(361,000$ workers), (59\%) from Indonesia, (13\%) Bangladesh and (28\%) are from others country Nepal, Myammar, India, Vietnam and Sri Langka. Through the study, the more foreign workers employed in the private projects, compared with projects under government tender.

\section{LITERATURE REVIEW}

The project under $10^{\text {th }}$ Malaysian Plan (10 MP) and Economic Transformation Programmed including Mass Rapid Transit (MRT) which costing over RM40 billion with required about 
130,000 construction skilled workers of various manpower of various trade both local and foreign workers to ensure successful completion (CIDB News, 2011)[9].The Malaysian construction industry has been experiencing a critical shortage of workforce. Nowadays the local workers unable to fulfill the demand of construction market from time being. This reason caused the contractor willing to import foreign workers from outside to meet the needs and requirement labor market in construction sector. According to Kwan Foh Kwai the President of MBAM (Master Builder Association of Malaysia) mentioned that, shortage of skilled construction workers is very crucial issues in construction industry (MBAM Online News)[10]. Besides that, MBAM also stated that, the acute shortage of skilled workers in the construction industry will give negative impact towards the projects under Malaysian Plan (10MP) and Economic Transformation Programmed (The Star Online) [11].

Current topical issues relevant to the Malaysia construction industry are the quality of workmanship. According to REHDA (Real Estate Housing Developers' Association Malaysia quality of product including housing and building are related directly to manpower and skilled. It seems that the construction workers is failed to attract workers in skilled and semi-skilled trades. The 3D perception has discouraged skilled local workers in joining, resulting in a lot of job being executed by the untrained construction workers. The important issue from REHDA stated that, the skilled labor shortage is the one of factor contributing of the increasing property price (The Stars Newspaper, 2011)[12].

The aim of this master project is to study the current construction labor shortage at construction projects in the district of Johor Baharu, Malaysia. In order to achieve this aim, four objectives are developed. The objectives are as follow to estimate the current labor shortage at construction sites, to evaluate the problem faced by contractor when hired labor, to examine contractor method of acquiring construction labor and to investigate the strategies taken by contractor to overcome shortage of labor.

\section{METHODOLOGY}

The main reason of the study is to fulfill earlier stated objectives though the collection of data using survey questionnaire forms. The methodology is set in order to gather the data to achieved the outlined of objectives.

The first step of study is to rationalize the issue to set up the topic of study. After that the statement of problems, aims and objectives were developed. This study required several methods of data collections for the purpose of objectives achievements. For the knowledge improvement phase, the literature review is carried out. The literature sources that connection with study including journal, books, conference papers, magazines and websites will be used in the literature review part. From that information, a set of questionnaire form that related to objectives will be developed. The question that develops in the questionnaire was in the form of multiple choice or open ended questions or Likert Scale. The respondents are among the contractors parties that involved in construction projects. The result obtained from questionnaire will be represent in data table, bar and pie chart, and radar plot. The data will be analyzed using statistical method that is mean or average index, frequencies and percentage calculation. The final phase of this study is to define the conclusion and recommendation with reference to the objective, subsequent to the analysis from the questionnaire.

The feedbacks provided by respondents are categorized into five options, Strongly Agree, Agree, Moderate/slightly agree, Disagree and Strongly Agree[13]. The Multiple-choice questions require the anticipation of the whole range of likely answers, which would be given, and formulating the options. The multiple-choice questions are based on Likert scale of five ordinal measures of agreement towards each statement (from 1 to 5).

\section{RESULTS AND DISCUSSIONS}

This study was conducted to study current construction labor shortage at construction projects in Johor Baharu. This chapter will discussed the analysis data of questionnaire that were obtain from respondent which is consist project representative that is project manager from the 35 construction sites in Johore Bahru.

The data analysis section is divided into four part according objectives. For the first objective that consists of demographic background or data which is consist of the number of shortage of workers in 35 construction sites. Meanwhile, for the others objective consist of Likert scale analysis consists of questions regarding to the problems facing by contractor when hired labor, contractor method of acquiring construction labor and the strategies taken by contractor to overcome shortage of labor.

\subsection{Objective 1}

Table 1 tabulates the current shortage of 35 construction project in area Johor Bahru. From the table indicates the shortages among project site survey are range from $4.17 \%$ until $44.44 \%$.Besides that, the percentage shortage for overall project is about $12.14 \%$ which is about 360 workers from the total existing labor workforce.

Beside that Chart 1 represent shortage of labor by category of labor. From the 360 numbers of workers shortage, the contractors needs $54 \%$ of skilled workers, $28 \%$ semi skilled and $18 \%$ unskilled workers in their construction projects. Others than that, from 360 workers, the contractors more considers to hired $80 \%$ of foreign construction workers and 
only $20 \%$ of local workforces. The types of labor are illustrated in the Chart 2.

Table - 1: Current Shortage of workers for Overall Project

\begin{tabular}{|c|c|c|c|c|}
\hline Code & $\begin{array}{c}\text { Existing } \\
\text { Workers }\end{array}$ & $\begin{array}{l}\text { Shortage of } \\
\text { Workers }\end{array}$ & $\begin{array}{c}\text { \% shortage per } \\
\text { project }\end{array}$ & $\begin{array}{c}\text { \% shortage for } \\
\text { overall project }\end{array}$ \\
\hline P1 & $\mathbf{3 2}$ & $\mathbf{0}$ & $\mathbf{0}$ & $\mathbf{0}$ \\
\hline P2 & $\mathbf{1 6 2}$ & $\mathbf{1 3}$ & $\mathbf{8 . 0 2}$ & $\mathbf{0 . 4 4}$ \\
\hline P3 & $\mathbf{1 2 0}$ & $\mathbf{5}$ & $\mathbf{4 . 1 7}$ & $\mathbf{0 . 1 7}$ \\
\hline P4 & $\mathbf{1 0 0}$ & $\mathbf{2 0}$ & $\mathbf{2 0}$ & $\mathbf{0 . 6 7}$ \\
\hline P5 & $\mathbf{5 7}$ & $\mathbf{1 3}$ & $\mathbf{2 2 . 8 1}$ & $\mathbf{0 . 4 4}$ \\
\hline P6 & $\mathbf{1 3}$ & $\mathbf{0}$ & $\mathbf{0}$ & $\mathbf{0}$ \\
\hline P7 & $\mathbf{1 5 0}$ & $\mathbf{5 0}$ & $\mathbf{3 3 . 3 3}$ & $\mathbf{1 . 6 9}$ \\
\hline P8 & $\mathbf{1 6 4}$ & $\mathbf{1 0}$ & $\mathbf{6 . 1 0}$ & $\mathbf{0 . 3 4}$ \\
\hline P9 & $\mathbf{1 1 5}$ & $\mathbf{0}$ & $\mathbf{0}$ & $\mathbf{0}$ \\
\hline P10 & $\mathbf{1 3 1}$ & $\mathbf{0}$ & $\mathbf{0}$ & $\mathbf{0}$ \\
\hline P11 & $\mathbf{4 5}$ & $\mathbf{0}$ & $\mathbf{0}$ & $\mathbf{0}$ \\
\hline P12 & $\mathbf{4 5}$ & $\mathbf{2 0}$ & $\mathbf{4 4 . 4 4}$ & $\mathbf{0 . 6 7}$ \\
\hline P13 & $\mathbf{1 2 9}$ & $\mathbf{6}$ & $\mathbf{4 . 6 5}$ & $\mathbf{0 . 2}$ \\
\hline P14 & $\mathbf{2 5}$ & $\mathbf{0}$ & $\mathbf{0}$ & $\mathbf{0}$ \\
\hline P15 & $\mathbf{5 0}$ & $\mathbf{7}$ & $\mathbf{1 4}$ & $\mathbf{0 . 2 4}$ \\
\hline P16 & $\mathbf{6 9}$ & $\mathbf{2 0}$ & $\mathbf{2 9}$ & $\mathbf{0 . 6 7}$ \\
\hline P17 & $\mathbf{2 5}$ & $\mathbf{5}$ & $\mathbf{2 0}$ & $\mathbf{0 . 1 7}$ \\
\hline P18 & $\mathbf{5 0}$ & $\mathbf{1 0}$ & $\mathbf{2 0}$ & $\mathbf{0 . 3 4}$ \\
\hline P19 & $\mathbf{2 5}$ & $\mathbf{5}$ & $\mathbf{2 0}$ & $\mathbf{0 . 1 7}$ \\
\hline P20 & $\mathbf{3 3}$ & $\mathbf{3}$ & $\mathbf{9 . 1}$ & $\mathbf{0 . 1}$ \\
\hline P21 & $\mathbf{1 0 2}$ & $\mathbf{1 2}$ & $\mathbf{1 1 . 7 6}$ & $\mathbf{0 . 4}$ \\
\hline P22 & $\mathbf{4 5}$ & $\mathbf{7}$ & $\mathbf{1 5 . 5 6}$ & $\mathbf{0 . 2 4}$ \\
\hline P23 & $\mathbf{3 6 1}$ & $\mathbf{4 4}$ & $\mathbf{1 2 . 1 9}$ & $\mathbf{1 . 4 8}$ \\
\hline P24 & $\mathbf{8}$ & $\mathbf{0}$ & $\mathbf{0}$ & $\mathbf{0}$ \\
\hline P25 & $\mathbf{1 5 3}$ & $\mathbf{4 0}$ & $\mathbf{2 6 . 1 4}$ & $\mathbf{1 . 3 5}$ \\
\hline P26 & $\mathbf{7 0}$ & $\mathbf{0}$ & $\mathbf{0}$ & $\mathbf{0}$ \\
\hline P27 & $\mathbf{5 7}$ & $\mathbf{0}$ & $\mathbf{0}$ & $\mathbf{0}$ \\
\hline P28 & $\mathbf{2 1 3}$ & $\mathbf{0}$ & $\mathbf{0}$ & $\mathbf{0}$ \\
\hline P29 & $\mathbf{2 2}$ & $\mathbf{5}$ & $\mathbf{2 2 . 7 3}$ & $\mathbf{0 . 1 7}$ \\
\hline P30 & $\mathbf{1 0}$ & $\mathbf{0}$ & $\mathbf{0}$ & $\mathbf{0}$ \\
\hline P31 & $\mathbf{2 0}$ & $\mathbf{0}$ & $\mathbf{0}$ & $\mathbf{0}$ \\
\hline P32 & $\mathbf{2 4 5}$ & $\mathbf{3 0}$ & $\mathbf{1 2 . 2 4}$ & $\mathbf{1 . 0 1}$ \\
\hline P33 & $\mathbf{9 4}$ & $\mathbf{3 1}$ & $\mathbf{3 2 . 9 8}$ & $\mathbf{1 . 0 5}$ \\
\hline P34 & $\mathbf{2 2}$ & $\mathbf{0}$ & $\mathbf{0}$ & $\mathbf{0}$ \\
\hline P35 & $\mathbf{3 3}$ & $\mathbf{4}$ & $\mathbf{1 2 . 1 2}$ & $\mathbf{0 . 1 3}$ \\
\hline Total & $\mathbf{2 9 6 4}$ & $\mathbf{3 6 0}$ & & $\mathbf{1 2 . 1 4}$ \\
\hline & & & & \\
\hline & & & & \\
\hline
\end{tabular}

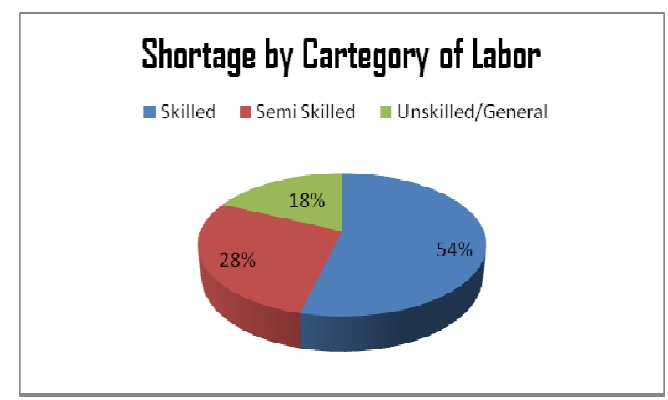

Chart - 1: Shortage by Category of Labor

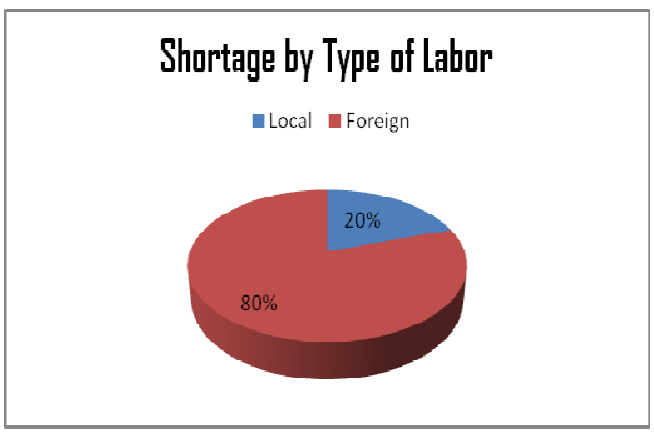

Chart - 2: Shortage by Type of Labor

\subsection{Objective 2}

The data analysis for the research objective no 2 which is "Evaluating Problem Faced by Contractor When Hired Labor", were conducted to evaluated the common problem faced by contractor when hired labor workforce. The research question/objective is represented by 12 items. The attainment for this section is by questionnaire survey. The research result findings are shown in Chart 3 and Table 2 as follow.

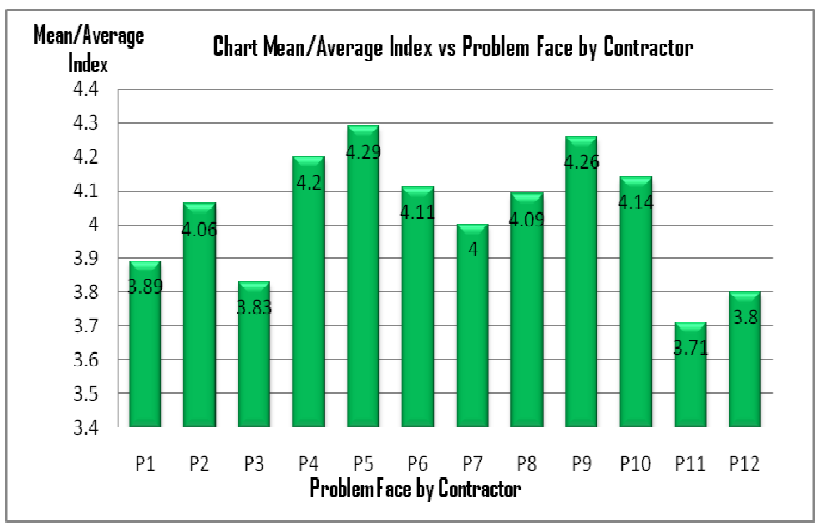

Chart - 3: Mean/Average Index and Problem Facing by Contractor when Hired Labor

Table - 2: Classification of Problem Face by Contractor

\begin{tabular}{|l|l|}
\hline P1 & Applications of employees permit from KDN \\
\hline P2 & Renewal/ extension of term of labor permit \\
\hline P3 & $\begin{array}{l}\text { Obtaining a certificate of proficiency/skill from } \\
\text { MLKV }\end{array}$ \\
\hline P4 & $\begin{array}{l}\text { document management and contract of employment } \\
\text { in immigration }\end{array}$ \\
\hline P5 & Recruitment and delivery cost of labor \\
\hline P6 & Medical Checkup screening cost with FOMEMA \\
\hline P7 & Foreign worker supply source from (CLAB) \\
\hline P8 & Raids on construction site by the authorities \\
\hline P9 & Levy that imposed by government \\
\hline P10 & Registration with job Malaysia agency \\
\hline P11 & Registration with job Malaysia agency \\
\hline P12 & Calling Visa \\
\hline
\end{tabular}

Chart 3 represent bar chart mean/average index on the problem facing by contractor start from item problem no 1 until problem no 12. From the chart show that the highest index is belonging to item problem no 5 which is problem on recruitment and delivery cost of labor. While the smallest mean index is on problem Registration with job Malaysia agency that is 3.71 averages/ means index. The higher value represent the priority or critical of that problem and vice versa. 


\subsection{Objective 3}

The data analysis of the objective number 3 which is "Examine Contractor Method of Acquiring Construction Labor", were conducted to confirm what the common contractor method of acquiring construction labor. The research objective is represented by 7 items. The attainment for this section is by questionnaire survey. The research result findings are shown in Chart 4 and Table 3 as follow.

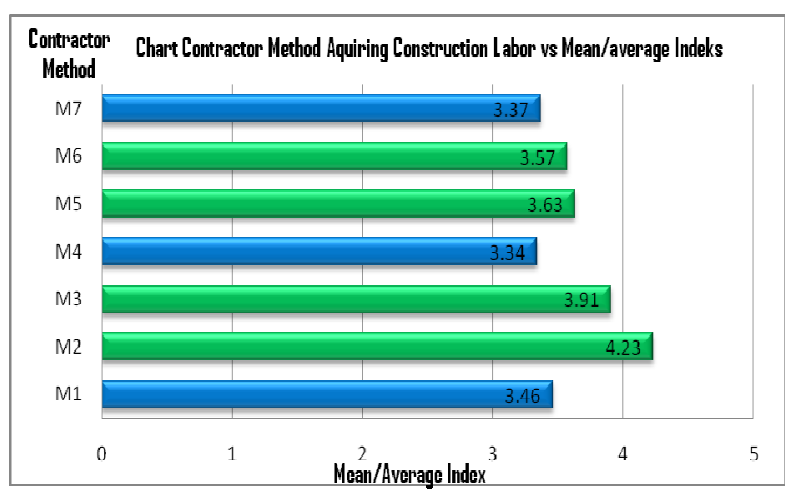

Chart - 4: Mean/Average Index and Contractor Method Acquiring Construction Labor

Table - 3: Code for Contractor Method in Acquiring Construction Labor

\begin{tabular}{|l|l|}
\hline M1 & Direct Intake from Labor Agent \\
\hline M2 & Through Subcontractor Method \\
\hline M3 & Gains from Sub Labor Parties \\
\hline M4 & $\begin{array}{l}\text { Applies From Department of Labor } \\
\text { Force (JT) }\end{array}$ \\
\hline M5 & Obtain labor force from CLAB \\
\hline M6 & $\begin{array}{l}\text { Direct Intake (advertising in mass } \\
\text { media) }\end{array}$ \\
\hline M7 & $\begin{array}{l}\text { Application through the Malaysia } \\
\text { Construction Acaderny (ABM) }\end{array}$ \\
\hline
\end{tabular}

Chart 4 illustrated bar chart of the mean/average index on contractor method acquiring construction labor start from item method no 1 until method no 12. From the chart above describing that the highest index is subjected towards item method no 2 which is acquiring labor through subcontractors and average mean index is 4.23 . Whereas the smallest mean index is reflected on method by applies from department of labor forces that is 3.34 averages/ means index. The higher value represents the popular or common method used by contractors while the smallest values indicate the less popular method applies by contractor in acquiring the labor workforces.

\subsection{Objective 4}

The data analysis for the objective number 4 which is "Strategies Taken by Contractors to Overcome Shortage of Labor", were conducted to investigate what the common approach taken by contractors to overcome shortage of labors. The research objective is represented by 10 items. The attainment for this section is by questionnaire survey. The research result findings are shown in Chart 5 and Table 4 as follow.

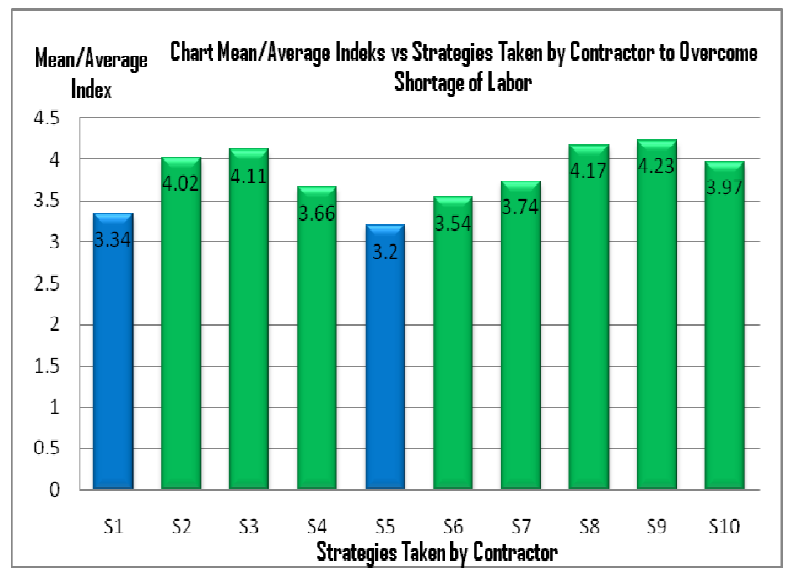

Chart - 5: Mean/Average Index of Strategies Taken by Contractor to Overcome Shortage of Labor

Table - 4: Code for Strategies Taken by Contractor

\begin{tabular}{|c|c|}
\hline S1 & Borrowing Labors from others Contractors \\
\hline $\mathrm{S} 2$ & $\begin{array}{l}\text { Rescheduling work and Resources Leveling } \\
\text { accordance labor resources available }\end{array}$ \\
\hline S3 & Instruct labors available to work overtime \\
\hline S4 & Instruct labors to work On Holidays \\
\hline S5 & Introduce Multiple shifts work system \\
\hline S6 & $\begin{array}{l}\text { Increasing the number of the machine or } \\
\text { machinery to accommodate shortage of } \\
\text { labor }\end{array}$ \\
\hline S7 & $\begin{array}{l}\text { Adopting new technologies like precast } \\
\text { formwork system or precast concrete (if } \\
\text { critical) }\end{array}$ \\
\hline S8 & Concentrating more on Critical Activities \\
\hline S9 & $\begin{array}{l}\text { Maximize used / fully optimize used of } \\
\text { labors available }\end{array}$ \\
\hline S10 & Hiring labor that having multiple skills \\
\hline
\end{tabular}

Chart 5 tabulated bar chart of the mean/average index on strategies taken by contractor to overcome shortage of labor start from item strategies no 1 until strategies no 10. From the 
chart above describing that the highest index is subjected towards item strategy item no 9 which is maximize/fully optimize used of labors available while the average mean index is 4.23 . Whereas the smallest mean index is reflected on strategy by introduce multiple shifts work system that is 3.2 averages/ means index. The higher value represents the popular or common strategy applied by contractors while the smallest values indicate the less popular strategy applies by contractor in to overcome shortage of the labor workforces.

\section{CONCLUSIONS}

From the result analysis and discussion, some of conclusion can be came out based on objectives of this study as follow the first objectives were to study the current shortage composition of construction labor. From the data analysis the current shortage composition for every project site surveyed is range from $4.17 \%$ until $44.44 \%$. Others than that, for overall project on the average is about $12.14 \%$ from total labor workforces. The second objective was to evaluate the problem faced by contractor when hired labor. From the findings the average/min index of problem face by contractor were ranging from 3.71-4.29. Therefore as conclusion the critical problem facing by contractors when hired labor is recruitment and delivery cost of labor. The third objective is to examine contractor method of acquiring construction labor. From the analysis indicates the average/min index of contractor method of acquiring construction labor was ranging from 3.34-4.23. Therefore as conclusion the common practice contractor method of acquiring construction labors is through subcontractor's method The final objective is to investigate the strategies taken by contractor to overcome shortage of labor. From the analysis highlighted the average/min index strategies taken by contractor to overcome shortage was ranging from 3.20-4.23. Therefore as conclusion the popular strategy practice by contractor to overcome shortage of labors is fully maximized or optimized used of labors available in construction projects.

\section{ACKNOWLEDGEMENTS}

We would like to thank our sponsor, Ministry of Higher Education (MOHE) and Universiti Teknologi Malaysia (UTM) for the financial support of Research University Grant (Vote No. Q.J130000.7122.03J11) which enable us to carry out this research project Thank you also to UTM Research Management Centre (RMC) and those who had contributed towards the completion of this research.

\section{REFERENCES}

[1] Zakaria, M.Y (2006) "Challenges in Providing Local Skilled Construction Workers" Universiti Teknologi Malaysia.

[2] Berita Harian "ABM Help in Reducing Dependance on foreign Workers" by Aivizanoorwani Shah Shahroni on $8^{\text {th }}$ July 2010
[3] Bernama, (2011) "Reduction of Foreign Workers Dependency Through IBS" website www.Bernama.com

[4] Migration News online (2 April 2011) "Southern Asia" logged www.migration.ucdavyis.edu.my asscess on 26 July 2011.

[5] Abdul Aziz (1995). Foreign Labour in the Malaysian Construction Industry (Geneva, International Labour Office.

[6] The Malaysian Insider online "Foreign Workers Levy Hike in 2011" $20^{\text {th }}$ May 2010 by Asrul Hadi Abdullah Sani, logged on www.malaysianinsider.com

[7] Malaysian Construction Summit 2008 - 6th June 2008, Paper presented by Datuk Ir. Hamzah Hasan, Chief Executive, CIDB.

[8] CIDB \& Cream (2010), "Latest Research on Construction Foreign Workers 2010" can be access though http://ibsresearch.blogspot.com/2010/09/kajian-status-terkiniperkerja-asing-di.html

[9] CIDB News, (2011). "Moving Forward" by Sazali Che mat.

[10] MBAM Online News "Skilled Manpower Shortage Need Urgent Attention" by Siti Sakinah Abdul Latiff on 4 august 2010, can be acess on www.MBAM.org.my

[11] The Star Online "Workers Shortage Could Hit ETP Plan" by Wong Pek Mei on 16 march 2011, can be access in www.Thestar.my

[12] The Star Newspaper on Star Biz Week "Your 10 Questions with Datuk Seri Michael Yam REHDA President". 25 June 2011

[13] Abd. Majid M.Z. and Ronald McCaffer, M.ASCE (1997), .Factors of Non Excusable Delays That Influence Contractor's Performance., Journal of Construction Engineering and Management, ASCE

\section{BIOGRAPHIES}

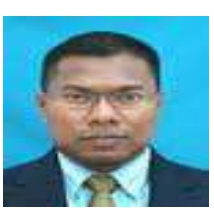

Abdul Rahim Abdul Hamid is a Senior Lecturer in Department of Structures and Materials, Faculty of Civil Engineering at Universiti Teknologi Malaysia, Skudai Johor, Malaysia since 1994. He holds a Master in Construction Engineering and BSc. in Civil Engineering Washington University, USA

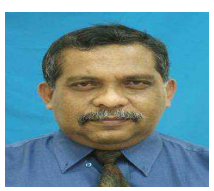

Bachan Singh a/l Besawa Jagar Singh is a Senior Lecturer in Department of Structures and Materials, Faculty of Civil Engineering at Universiti Teknologi Malaysia, Skudai Johor, Malaysia.

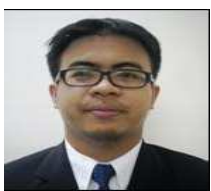

Muhammad Shahrom Mazlan is a Project Engineer working with a Piling Company. $\mathrm{He}$ was a post-graduate student of Construction Management in Faculty of Civil Engineering at Universiti Teknologi Malaysia, Skudai Johor, Malaysia. 